\title{
Penerapan Fitur Warna dan Tekstur untuk Identifikasi Kerusakan Mutu Biji Kopi Arabika (Coffea Arabica) di Kabupaten Bondowoso
}

\author{
Zilvanhisna Emka Fitri' ${ }^{1}$, Brilyan Andi Syahbana ${ }^{2}$, Abdul Madjid ${ }^{3}$, Arizal Mujibtamala \\ Nanda Imron ${ }^{4}$ \\ 1,2Teknik Informatika, Jurusan Teknologi Informasi, Politeknik Negeri Jember \\ ${ }^{3}$ Budidaya Tanaman Perkebunan, Jurusan Produksi Pertanian, Politeknik Negeri Jember \\ ${ }^{4}$ Teknik Elektro, Jurusan Teknik Elektro, Fakultas Teknik, Universitas Jember \\ ${ }^{1}$ zilvanhisnaef@ polije.ac.id, ${ }^{2}$ brilyan.andi@gmail.com, ${ }^{3}$ abdul_madjid@ polije.ac.id, \\ 4arizal.tamala@unej.ac.id
}

\begin{abstract}
ABSTRAK. Tanaman perkebunan yang juga menjadi sumber devisa negara Indonesia adalah kopi. Hanya dua jenis kopi yang bernilai ekonomis untuk dibudidayakan yaitu kopi arabika dan kopi robusta. Bondowoso merupakan kabupaten di Jawa Timur yang mengembangkan kopi arabika. Permasalahannya adalah petani masih menggunakan pengamatan langsung (manual) pada masing-masing biji kopi untuk menentukan kualitas biji kopi sehingga penelitian ini diharapkan mampu membantu petani dalam sortasi kerusakan mutu biji kopi berdasarkan warna dan teksturnya. Fitur yang digunakan yaitu fitur warna dan fitur tekstur GLCM pada sudut $0^{\circ}$ dan 45. Jumlah data keseluruhan adalah 198. Metode Backpropagasi mampu mengklasifikasi kerusakan mutu pada biji kopi arabika dengan tingkat akurasi training sebesar 100\% dan tingkat akurasi testing sebesar $97.5 \%$ pada variasi learning rate yaitu 0.5 .
\end{abstract}

Kata Kunci: Kerusakan mutu; Biji Kopi Arabika; Warna; GLCM; Backpropagasi

\begin{abstract}
Plantation crops are also a source of foreign exchange Indonesia is coffee. There are only two types of coffee that have economic value for cultivation, namely Arabica coffee and Robusta coffee. Bondowoso is a district in East Java that develops Arabica coffee. The problem is that farmers still use direct observation (manual) on each coffee bean to determine the quality of coffee beans so that this research is expected to be able to assist farmers in sorting the damage to the quality of coffee beans based on color and texture. The features used are color features and GLCM texture features at $0^{\circ}$ and $45^{\circ}$ angles. The total number of data is 198 . The Backpropagation method is able to classify quality damage to Arabica coffee beans with a training accuracy rate of $100 \%$ and a testing accuracy rate of $97.5 \%$ at a learning rate variation of 0.5 . Keywords: Quality damage; Arabica Coffee Beans; Color; GLCM; Backpropagation
\end{abstract}

\section{PENDAHULUAN}

Tanaman perkebunan yang juga menjadi sumber devisa negara Indonesia adalah kopi. Data menyebutkan bahwa salah satu provinsi penghasil kopi adalah Provinsi Jawa Timur. Jumlah produksinya mencapai 63.760 ton pada tahun 2018 (Badan Pusat Statistik, 2018). Terdapat empat varietas kopi yang dibudidayakan, namun yang memiliki nilai ekonomis tinggi adalah kopi arabika dan kopi robusta (Rahardjo, 2012). Persentase varietas kopi arabika dibudidayakan sebesar $20 \%$ kopi arabika sedangkan sisanya adalah kopi robusta. Berkurangnya tingkat produksi kopi arabika dikarenakan tempat tumbuhnya. Kopi Arabika dapat tumbuh di dataran dengan ketinggian $\geq 1000$ meter di atas permukaan laut (dpl) (Ega Ash Yokawati \& Wachjar, 2019). Factor lain adalah tidak tahannya kopi arabika terhadap penyakit khususnya penyakit karat daun (Rahardjo, 2012). Kabupaten Bondowoso adalah salah satu kabupaten di Jawa timur yang mengembangkan kopi arabika. Permasalahannya adalah petani masih menggunakan pengamatan langsung (manual) pada masing-masing biji kopi untuk menentukan kualitas biji kopi, penentuan kualitas biji kopi ini bereferesi di SNI-01-2970-2008. Proses sortase tersebut dinilai kurang efektif dan akurat sehingga dibuatlah sebuah sistem otomatis yang mampu membantu petani saat sortir mutu biji kopi arabika.

Penelitian yang menjadi acuan peneliti terkait kopi adalah Identifikasi jenis dan mutu kopi menggunakan fitur R, G, B, entropy, energy, homogenity, dan contrast, kemudian algoritma klasifikasi yang digunakan adalah Learning Vector Quantization (LVQ) sehingga menghasilkan tingkat akurasi sebesar 73.7\% (Effendi et al., 2017). Selain menggunakan LVQ, metode klasifikasi lain yang digunakan adalah Multilayer Perceptron Neural Network (MLPNN). Pada penelitian tersebut terdapat dua kelas mutu kopi arabika baik dan mutu kopi arabika buruk dengan fitur yang digunakan adalah warna, area dan roundness. Metode MLPNN mampu mengklasifikasi kedua mutu tersebut dengan tingkat akurasi sebesar 94.10\% (Pizzaia et al., 2019). Backpropagation juga digunakan dalam mengenali level warna pada biji kopi sangrai (Level of roast coffee) 
menggunakan parameter tekstur GLCM. Tingkat akurasi yang didapatkan yaitu $97.5 \%$ (Nasution \& Andayani, 2017). Selain metode LVQ dan Backpropagation, metode klasifikasi KNN juga digunakan dalam mengklasifikasi mutu greenbean kopi arabika lanang dan biasa berdasarkan fitur bentuk serta menghasilkan akurasi sebesar $69.8 \%$ (Ikhsan et al., 2020).

Berdasarkan uraian diatas maka peneliti akan mengklasifikasi kerusakan mutu biji kopi arabika berdasarkan parameter warna dan tekstur GLCM menggunakan metode klasifikasi Backpropagation. Perbedaan dengan penelitian sebelumnya adalah kelas yang menjadi output metode ini. Kerusakan mutu biji kopi terlihat dari perubahan warnanya yaitu kopi hitam, kopi coklat dan kopi berkulit tanduk. Sedangkan biji kopi arabika dianggap normal bila berwarna hijau keabuan. Hal ini tentu berbeda dari penelitian sebelumnya yang dilakukan oleh Pizzaia yang meneliti tingkat warna sangrai pada kopi arabika dan penelitian Ikhsan yang focus pada klasifikasi mutu kopi arabika berdasarkan keutuhan bentuk biji kopi.

\section{METODE PENELITIAN}

Data citra biji kopi arabika didapatkan berdasarkan studi kasus yang telah di lakukan di Kabupaten Bondowoso tepatnya di Kecamatan Ijen. Data citra biji kopi yang digunakan adalah data pribadi peneliti yang telah mengacu pada SNI-01-2970-2008 sehingga mutu biji kopi arabika dibagi menjadi 4 kelas yaitu normal, hitam, coklat dan kulit tanduk yang digambarkan pada Gambar 1.

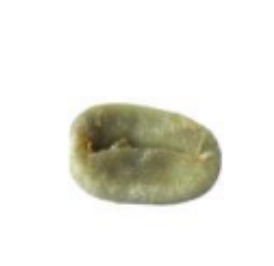

Normal

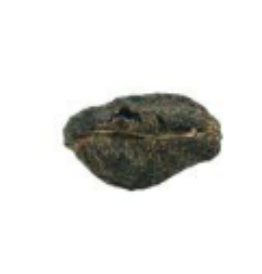

Hitam

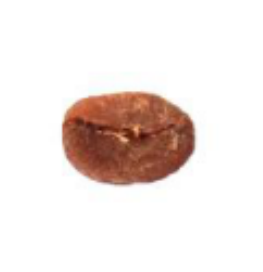

Coklat

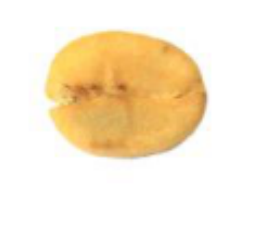

Kulit Tanduk

Gambar 1. Variasi Kerusakan Mutu pada Citra Biji Kopi Arabika

Beberapa tahapan yang dilakukan adalah pengambilan sampel citra biji kopi arabika, preprocessing, ekstraksi fitur dan klasifikasi kerusakan mutu biji kopi arabika yang ditunjukkan pada Gambar 2.

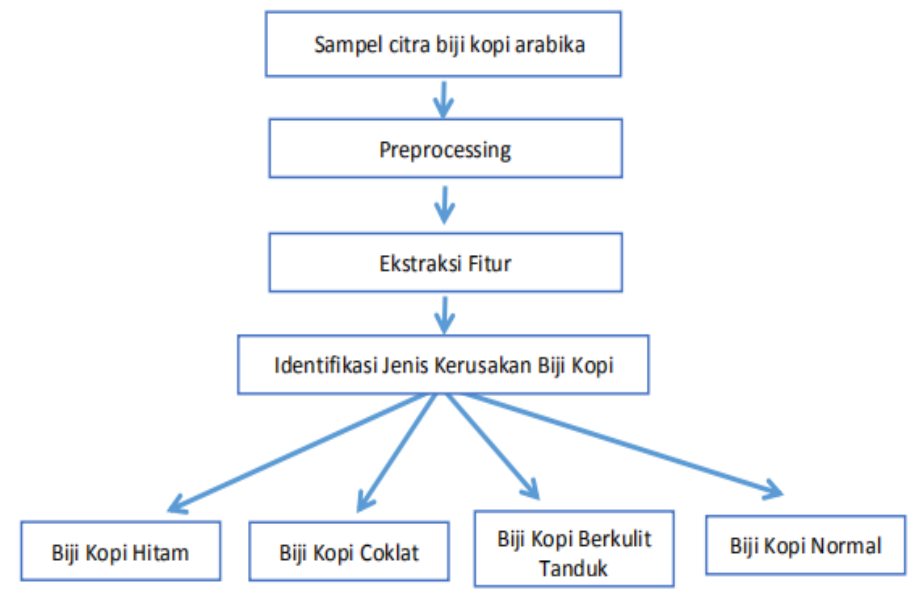

Gambar 2. Tahapan Penelitian Identifikasi Kerusakan Mutu Biji Kopi Arabika

\subsection{Sampel Citra Biji Kopi Arabika}

Pengambilan citra biji kopi arabika menggunakan kamera digital dengan resolusi $18 \mathrm{MP}$, selain itu digunakan mini studio. Waktu pengambilan data dilakukan pada pukul 14.00 sampai dengan 16.00 WIB karena diperlukan pencahayaan yang maksimal sehingga berdampak pada kualitas citra biji kopi arabika yang dihasilkan. Hasil citra biji kopi ditunjukkan pada Gambar 1.

\subsection{Preprocessing Citra}

Preprocessing citra merupakan tahapan yang bertujuan untuk perbaikan kualitas citra dan normalisasi data citra. Salah satu contohnya adalah tahapan cropping, tujuannya untuk memotong citra yang semula 
berukuran 5184 x3456 piksel menjadi lebih kecil yaitu sebesar 151 x 151 piksel. Perbandingan citra sebelum dan sesudah proses cropping dapat dilihat pada Gambar 3.

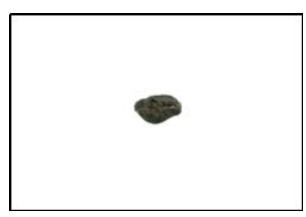

(a)

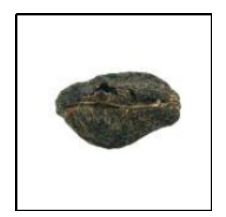

(b)

Gambar 3. (a) Citra Asli dan (b) Citra Hasil Cropping

\subsection{Ekstraksi Fitur}

Tujuan dari proses ektraksi fitur adalah untuk mengambil nilai ciri khusus (unik) dari setiap citra biji kopi arabika. Pada tahapan ini digunakan dua tahapan yaitu tahap pengambilan nilai komponen red, green, dan blue dari setiap citra. Kemudian dilakukan pemecahan komponen RGB dari setiap citra (Fitri, Rizkiyah, et al., 2020), proses selanjutnya dilakukan proses segmentasi. Tahapan selanjutnya adalah ekstraksi fitur menggunakan Gray Level Co-occurance Matrix (GLCM), beberapa fitur GLCM yang digunakan adalah kontras, angular second moment, inverse different moment, korelasi dan entropi pada sudut $0^{\circ}$ dan $45^{\circ}$ (Fitri, Nuhanatika, et al., 2020).

\subsection{Klasifikasi dan Identifikasi Kerusakan Mutu Biji Kopi Arabika}

Metode klasifikasi yang digunakan metode backpropagation. Backpropagation merupakan metode neural network yang algoritma pembelajarannya adalah supervised learning. Supervised learning adalah metode pembelajaran dimana target klasifikasi sudah diketahui. Kelebihan dari metode ini adalah jika hasil output sistem tidak sesuai dengan target klasifikasi maka akan dilakukan pembaruan bobot, sehingga diharapkan terjadi peningkatan tingkat akurasi (Nanda Imron \& Fitri, 2019).

\section{HASIL DAN PEMBAHASAN}

Pada penelitian ini merupakan penerapan computer vision untuk identifikasi kerusakan mutu biji kopi arabika. Tahapan awal penelitian yaitu proses cropping yang ditunjukkan di Gambar 3. Selanjutnya akan kami bahas terkait hasil ekstraksi fitur warna, proses segmentasi dan ekstraksi fitur tekstur GLCM.

\subsection{Ekstraksi Fitur Warna}

Pada Gambar 1 menunjukkan bahwa untuk mengklasifikasi dan mengidentifikasi kerusakan mutu biji kopi arabika menggunakan fitur warna, hal tersebut dipilih karena terjadi perbedaan warna antara kopi hitam, kopi coklat, kopi berkulit tanduk dan kopi normal. Oleh karena itu citra ditampilkan dengan komponen red, green dan blue seperti yang ditunjukkan pada Gambar 4, sementara nilai ekstraksi fitur warna ditampilkan pada Tabel 1.

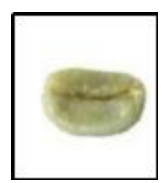

Citra RGB

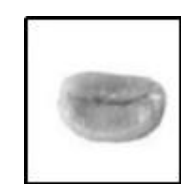

Channel Red

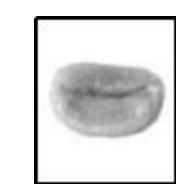

Channel Green

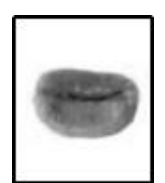

Channel Blue

Gambar 4. Citra Hasil Parameter Warna pada Ruang Warna RGB

Tabel 1. Hasil Rata - Rata Parameter Warna RGB pada Masing-Masing Kelas

\begin{tabular}{cccc}
\hline Kelas Biji Kopi Arabika & Channel Red & Channel Green & Channel Blue \\
\hline Coklat & 237.70 & 226.78 & 223.17 \\
Hitam & 224.71 & 224.87 & 223.23 \\
Kulit Tanduk & 247.11 & 234.49 & 213.97 \\
Normal & 229.73 & 230.63 & 222.13 \\
\hline
\end{tabular}

Tabel 1 menunjukkan bahwa terdapat kemiripan nilai pada parameter channel blue pada kelas Biji Kopi Arabika Normal, Biji Kopi Arabika Hitam dan Biji Kopi Arabika Coklat. Dimana parameter channel blue pada kelas Biji Kopi Arabika Normal yaitu 222.13, sedangkan pada kelas hitam 223.23 dan pada kelas coklat 223.17. 
Ekstraksi fitur selanjutnya adalah fitur tekstur GLCM, namun sebelum dilakukan proses tersebut, dilakukan proses segmentasi dengan cara mengurangi antara citra Channel Red dengan citra Channel Blue. Proses tersebut bertujuan untuk mendapatkan citra hasil segmentasi yang mewakili atau merepresentasikan nilai keabuan pada masing-masing kelas, seperti yang ditunjukkan pada Gambar 5.
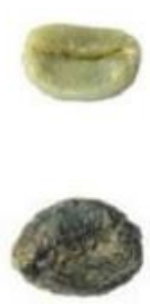

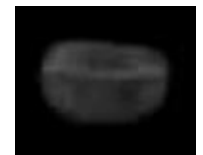

(a)

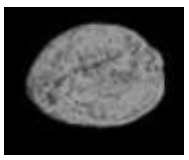

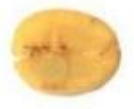

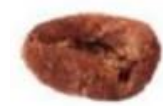

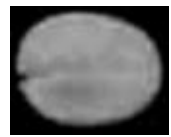

(b)

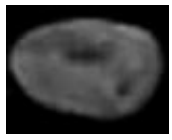

(c)

(d)

Gambar 5. Hasil Citra Segmentasi pada Kelas (a) Biji Kopi Arabika Normal, (b) Biji Kopi Arabika Kulit Tanduk, (c) Biji Kopi Arabika Hitam dan (d) Biji Kopi Arabika Coklat.

Gambar 5 menunjukkan bahwa biji kopi arabika hitam terlihat jelas teksturnya bila dibandingkan dengan biji kopi arabika kulit tanduk, biji kopi arabika coklat dan biji kopi arabika normal. Tentu saja nilai tingkat keabuan (gray level) juga akan berbeda pada masing-masing kelas biji kopi. Oleh sebab itu dilakukan lagi pengambilan fitur tekstur berdasarkan nilai Gray Level Co-Occurrence Matrix (GLCM).

\subsection{Ekstraksi Fitur Tekstur GLCM}

Proses selanjutnya adalah ekstraksi fitur citra menggunakan GLCM. Ciri GLCM yang digunakan antara lain kontras, angular second moment, inverse different moment, korelasi dan entropi pada sudut $0^{\circ}$ dan sudut 45. Hasil ekstraksi fitur GLCM pada sudut $0^{\circ}$ ditunjukkan pada Tabel 2 dan Tabel 3 untuk sudut 45. Pada Tabel 2 , rata-rata nilai fitur inverse different moment (IDM) pada sudut $0^{\circ}$ menunjukkan adanya kemiripan nilai antara kelas biji kopi arabika normal dan biji kopi arabika coklat yaitu 0.86, sedangkan kelas biji kopi arabika hitam memiliki kemiripan nilai dengan kelas biji kopi arabika kulit tanduk yaitu 0.80. Sedangkan pada fitur angular second moment (ASM), nilai kelas biji kopi arabika hitam memiliki kemiripan nilai dengan kelas biji kopi arabika coklat.

Tabel 2. Hasil Rata - Rata Parameter Tekstur GLCM Sudut $0^{\circ}$

\begin{tabular}{llllll}
\hline Biji Kopi Arabika & Kontras & ASM & IDM & Korelasi & Entropi \\
\hline Coklat & 8.85 & 0.60 & 0.86 & 0.0010 & 2.01 \\
Hitam & 140.11 & 0.60 & 0.80 & 0.0005 & 2.28 \\
Kulit Tanduk & 16.02 & 0.43 & 0.80 & 0.0003 & 2.89 \\
Normal & 2.19 & 0.53 & 0.86 & 0.0046 & 2.19 \\
\hline
\end{tabular}

Tabel 3. Hasil Rata - Rata Parameter Tekstur GLCM Sudut $45^{\circ}$

\begin{tabular}{llllll}
\hline Biji Kopi Arabika & Kontras & ASM & IDM & Korelasi & Entropi \\
\hline Coklat & 23.28 & 0.59 & 0.82 & 0.0010 & 2.12 \\
Hitam & 239.61 & 0.59 & 0.79 & 0.0005 & 2.31 \\
Kulit Tanduk & 45.78 & 0.42 & 0.75 & 0.0003 & 3.06 \\
Normal & 5.24 & 0.52 & 0.81 & 0.0046 & 2.34 \\
\hline
\end{tabular}

Tabel 3 terjadi kemiripan nilai pada parameter angular second moment (ASM) pada sudut $45^{\circ}$. Nilai fitur ASM kelas biji kopi arabika hitam dan kelas biji kopi arabika coklat yaitu 0.59, sedangkan pada kelas biji kopi arabika normal 0.52. Hasil tersebut nantinya berpengaruh pada hasil klasifikasi sistem, mengingat banyaknya parameter yang menunjukkan kemiripan pada masing-masing kelas biji kopi arabika.

\subsection{Klasifikasi dan Identifikasi Kerusakan Mutu Biji Kopi Arabika}

Metode klasifikasi yang digunakan metode backpropagation. Backpropagation merupakan metode neural network yang algoritma pembelajarannya adalah supervised learning. Supervised learning adalah metode pembelajaran dimana target klasifikasi sudah diketahui. Jumlah data yang digunakan 198 data yang terbagi menjadi 158 untuk data latih dan 40 untuk data uji. Nilai error yang digunakan adalah 0.00000001, 
maksimal iterasi (epoch) 100 dan target yang digunakan adalah 4 kelas. Arsitektur jaringan yang digunakan adalah neuron pada input sebanyak 13, neuron hidden layer sebanyak 19 dan neuron outputnya adalah 4. Tampilan sistem identifikasi kerusakan mutu biji kopi arabika ditunjukkan pada Gambar 6. Hasil pelatihan dan pengujian jaringan syaraf tiruan ditampilkan dalam Tabel 4

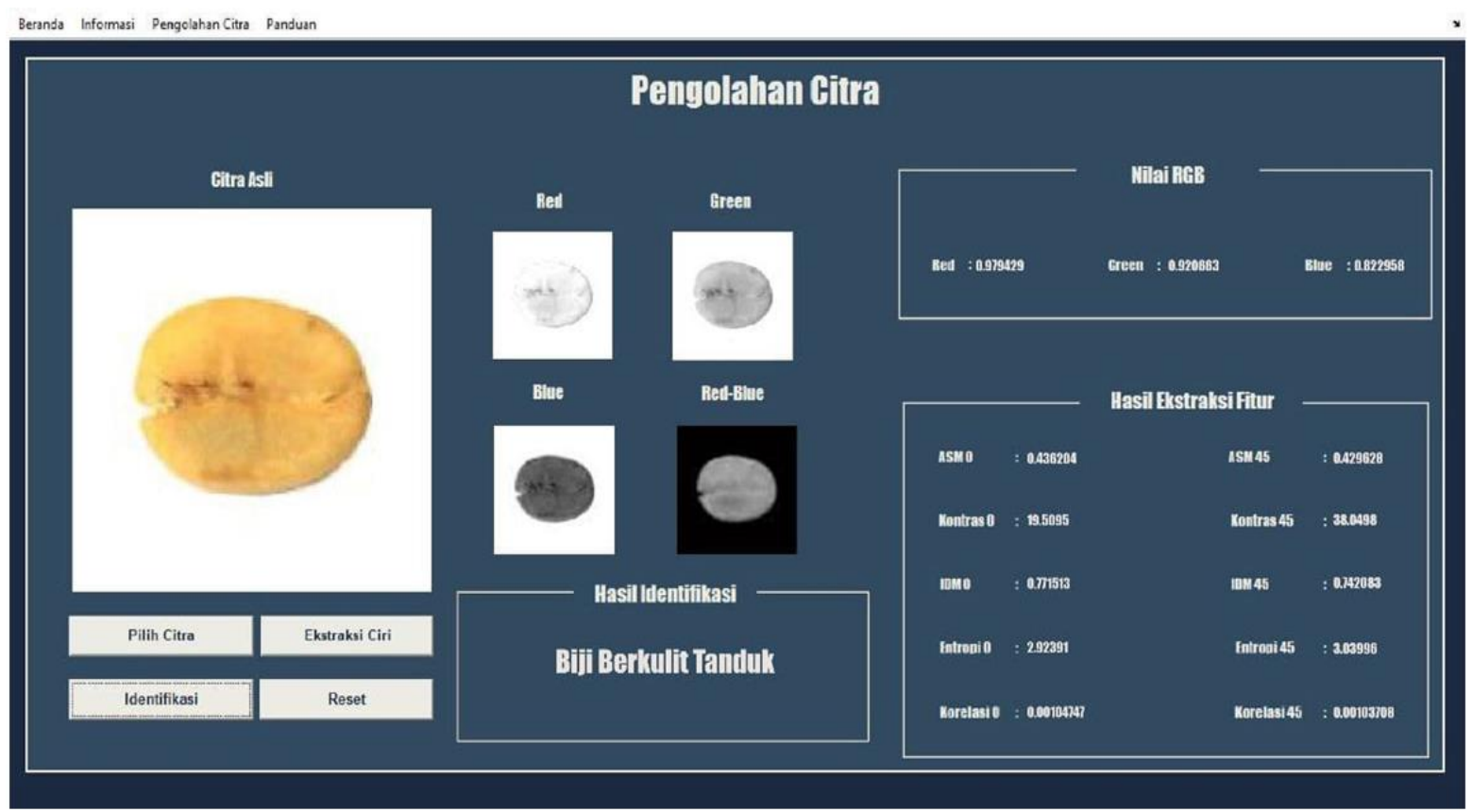

Gambar 6. GUI Sistem Identifikasi Kerusakan Mutu Biji Kopi Arabika

Tabel 4. Hasil Persentase Akurasi Metode Backpropagation dengan Variasi Learning Rate

\begin{tabular}{cccc}
\hline Epoch (Iterasi) & Learning Rate & Training Accuracy & Testing Accuracy \\
\hline 67 & 0.1 & $100 \%$ & $90 \%$ \\
15 & 0.2 & $98.10 \%$ & $72.5 \%$ \\
58 & 0.3 & $99.37 \%$ & $95 \%$ \\
31 & 0.4 & $99.37 \%$ & $87.5 \%$ \\
13 & 0.5 & $100 \%$ & $97.5 \%$ \\
\hline
\end{tabular}

Tabel 4 menunjukkan bahwa hasil training dengan menggunakan 158 data latih didapatkan tingkat akurasi tertinggi yaitu 100\% dengan variasi learning rate sebesar 0.1 dan 0.5 serta jumlah iterasi sebanyak 67 dan 13, sementara pada variasi learning rate sebesar 0.2 dengan jumlah epoch 15 yaitu didapatkan tingkat akurasi terendah sebesar $98.10 \%$. Namun pada proses testing didapatkan tingkat akurasi sebesar $90 \%$ dengan variasi learning rate 0.1 dan pada variasi learning rate 0.5 didapatkan $97.5 \%$. Tingkat akurasi tersebut didapatkan dari perhitungan yang berasal dari confusion matrix yang ditunjukkan pada Gambar 8.

\begin{tabular}{|c|c|c|c|c|c|}
\hline & Normal & Hitam & Coklat & Kulit Tanduk & Total \\
\hline Normal & 10 & 0 & 0 & 0 & 10 \\
\hline Hitam & 0 & 10 & 0 & 0 & 10 \\
\hline Coklat & 0 & 0 & 9 & 1 & 10 \\
\hline Kulit Tanduk & 0 & 0 & 0 & 10 & 10 \\
\hline Total & 9 & 9 & 9 & 11 & 40 \\
\hline
\end{tabular}

Gambar 7. Confusion Matrix Pengujian Metode Klasifikasi Backpropagation

Gambar 8 menunjukkan bahwa metode klasifikasi backpropagation salah mengenali data uji dengan kelas biji kopi arabika coklat dan dikenali serta diklasifikasikan menjadi biji kopi arabika kulit tanduk. Hal ini 
bisa terjadi karena nilai fitur warna dan tekstur GLCM memiliki kemiripan nilai antara kelas biji kopi arabika coklat dan kelas biji kopi arabika kulit tanduk.

\section{Kesimpulan}

Berdasarkan hasil penelitian yang telah dilakukan, dapat disimpulkan bahwa untuk mengidentifikasi kerusakan mutu biji kopi arabika menggunakan fitur warna dan tekstur GLCM. Metode backpropagasi mampu mengklasifikasi dan mengidentifikasi kerusakan mutu bijikopi arabika dengan tingkat akurasi $100 \%$ pada pelatihan dan $97.5 \%$ pada pengujian menggunakan variasi learning rate sebesar 0.5 .

\section{DAFTAR RUJUKAN}

Badan Pusat Statistik. (2018). Statistik Kopi Indonesia (S. D. S. T. Perkebunan (ed.)).

Effendi, M., Fatasya, U., \& Effendi, U. (2017). Identifikasi Jenis dan Mutu Kopi Menggunakan Pengolahan Citra Digital dengan Metode Jaringan Syaraf Tiruan. Jurnal Ilmiah Teknologi Pertanian AGROTECHNO, 2(1), 140-146.

Ega Ash Yokawati, Y., \& Wachjar, A. (2019). Pengelolaan Panen dan Pascapanen Kopi Arabika (Coffea arabica L.) di Kebun Kalisat Jampit, Bondowoso, Jawa Timur. Buletin Agrohorti, 7(3), 343-350. https://doi.org/10.29244/agrob.v7i3.30471

Fitri, Z. E., Nuhanatika, U., Madjid, A., \& Imron, A. M. N. (2020). Penentuan Tingkat Kematangan Cabe Rawit (Capsicum frutescens L.) Berdasarkan Gray Level Co-Occurrence Matrix. Jurnal Teknologi Informasi dan Terapan, 7(1), 1-5. https://doi.org/10.25047/jtit.v7i1.121

Fitri, Z. E., Rizkiyah, R., Madjid, A., \& Imron, A. M. N. (2020). Penerapan Neural Network untuk Klasifkasi Kerusakan Mutu Tomat. Jurnal Rekayasa Elektrika, 16(1), 44-49. https://doi.org/10.17529/jre.v16i1.15535

Ikhsan, D., Utami, E., \& Wibowo, F. W. (2020). Metode Klasifikasi Mutu Greenbean Kopi Arabika Lanang Dan Biasa Menggunakan K-Nearest Neighbor Berdasarkan Bentuk. Jurnal Ilmiah SINUS, 18(2), 1. https://doi.org/10.30646/sinus.v18i2.456

Nanda Imron, A. M., \& Fitri, Z. E. (2019). A Classification of Platelets in Peripheral Blood Smear Image as an Early Detection of Myeloproliferative Syndrome Using Gray Level Co-Occurence Matrix. Journal of Physics: Conference Series, 1201(1). https://doi.org/10.1088/1742-6596/1201/1/012049

Nasution, T. H., \& Andayani, U. (2017). Recognition of Roasted Coffee Bean Levels using Image Processing and Neural Network. Journal of Physics: Conference Series, 180(1), 1-8. https://doi.org/10.1088/1742$6596 / 755 / 1 / 011001$

Pizzaia, J. P. L., Salcides, I. R., Almeida, G. M. De, Contarato, R., \& Almeida, R. De. (2019). Arabica coffee samples classification using a Multilayer Perceptron neural network. 2018 13th IEEE International Conference on Industry Applications, INDUSCON 2018 - Proceedings, December 2019, 80-84. https://doi.org/10.1109/INDUSCON.2018.8627271

Rahardjo, P. (2012). Kopi: Panduan Budi Daya dan Pengolahan Kopi Arabika dan Robusta (1 ed.). Penebar Swadaya. 